\title{
TRIBUTE TO SAMUEL EFRON
}

\author{
by Stephen L. Gibson
}

Samuel Efron died on January 4 of this year at the age of eighty-one. In many ways he epitomized the international law practitioner of his generation.

Sam was an intellectual and, at the same time, an immensely practical lawyer. He brought his skills, and his humor, to bear in a number of roles throughout his long and varied career. Upon his graduation from Harvard Law School he came to Washington in the heady days of the New Deal, starting with the Securities and Exchange Commission in 1939. During World War II he served with the Navy in the Pacific and for a time in post-war Japan. Upon his return to civilian life, he worked in the Office of Alien Property, Department of Justice, and then moved to the Department of Defense to assume the newly created position of Assistant General Counsel for International Security Affairs.

Sam left the Government in 1954 to become a founding partner in the law firm of Surrey, Karasik, Gould \& Efron, where he specialized in international financial matters. In 1961 he accepted the position of Executive Vice President at Parsons \& Whittemore, where he was responsible for negotiation and implementation of pulp and paper projects in countries around the world. Sam resigned from P\&W in 1968 to join the law firm of Arent Fox Kintner Plotkin \& Kahn, where he established the firm's international law practice. He actively practiced law until, and beyond, his retirement in 1991, and he continued to come into the office up to the time of his final illness.

One of Sam's first clients at Arent Fox was a consortium of Finnish businesses, and over the years Sam developed a deep and close relationship with the business leaders of Finland. In recognition of his friendship and wise counsel the Government of Finland awarded Sam the Order of the Lion of Finland, Knight First Class, in 1975 and Commander of Order of the Lion of Finland in 1995.

Sam provided his counsel not only to his clients, but also to civic and educational institutions, serving as a member of the Board of Trustees of Meridian International Center, the Board of Directors of the United Nations Association of the National Capital Area, the Visitors Committee on International Relations of his alma mater, Lehigh University, the Visitors Committee of the Harvard School of Public Health, and the Board of the University of Virginia Medical School.

I would like to let Sam close this memoriam himself. In a 1989 interview, he said:

I really like my clients and I like the creativity of the international practice.... All in all, the international practice has these two great elements: number one, it calls for creativity and the ability to communicate "both orally and in writing" and it also is the last of the general practices.

It is important that the practice not become materialistic and lose the warmth of relations with clients, which I have tried to create.

Sam will be remembered for the way he lived these words, the example he set for others, and his contributions to the international community in which he lived. 